\title{
Faktor-Faktor yang Berhubungan dengan Kejadian Abortus Inkomplit di RSUD Cibinong Kabupaten Bogor
}

\author{
Alan Pardillah ${ }^{\mathbf{1}}$, Rina Afrina ${ }^{2}$ \\ ${ }^{1,2}$ Program Studi Sarjana Keperawatan \\ STIKes Indonesia Maju, Jakarta - Indonesia \\ Email: ${ }^{1}$ alanpardillah17@gmail.com, ${ }^{2}$ rinaafrina@gmail.com
}

\begin{abstract}
Latar Belakang: Abortus merupakan salah satu penyebab kematian ibu. Pendekatan etiologi merupakan cara terbaik dalam upaya menurunkan mortalitas dan morbiditas akibat abortus yang kejadiannya dipengaruhi oleh beberapa faktor risiko. Tujuan: Tujuan: dari penelitian ini adalah untuk mengetahui FaktorFaktor yang Berhubungan dengan Kejadian Abortus Inkomplit di RSUD Cibinong Kabupaten Bogor.

Metode: Populasi dalam penelitian ini adalah seluruh ibu hamil yang mengalami abortus inkomplit di RSUD Cibinong terdapat 145 kasus, sempel yang masuk kedalam kriteria penelitian terdapat 86 kasus Abortus Inkomplit. Jenis data yang digunakan pada penelitian ini adalah data sekunder. Pengumpulan data dilakukan dengan cara mengambil rekamedik dirumah sakit umum daerah cibinong. Analisa data menggunakan uji chi square. Hasil: Untuk interpretasi hasil menggunakan derajat kemaknaan $(\alpha)$ sebesar 5\%, dengan catatan jika $\mathrm{p}<0,05$ maka Ho ditolak dan Ha diterima. Hasil: Hasil penelitian ini adalah Ada hubungan usia dengan kejadian abortus inkomplit Di Rsud Cibinong Kabupaten Bogor Tahun 2017, hasil uji statistik diperoleh $\mathrm{P}$ Value $=0,001$ (P-value $<0,05)$. Ada hubungan paritas dengan kejadian abortus inkomplit, hasil uji statistik diperoleh $\mathrm{P}$ Value $=0,019$ (P-value $<$ $0,05)$. Ada hubungan abortus sebelumnya dengan kejadian abortus inkomplit hasil uji statistik diperoleh $\mathrm{P}$ Value $=0,009$ (P-value $<$ 0,05).

Kesimpulan: Dari hasil penelitian yang didapatkan dilapangan agar dapat dijadikan masukan bagi pengembangan ilmu dan pengetahuan serta menjadi sumber pustaka bagi mahasiswa yang akan datang.
\end{abstract}

Kata Kunci: Abortus, Usia, Paritas, Kejadian Abortus Inkomplit.

Editor: WN

Hak Cipta:

(C)2021 Artikel ini memiliki akses terbuka dan dapat didistribusikan berdasarkan ketentuan Lisensi Atribusi Creative Commons, yang memungkinkan peng-gunaan, distribusi, dan reproduksi yang tidak dibatasi dalam media apa pun, asalkan nama penulis dan sumber asli disertakan. Karya ini dilisensikan di bawah Lisensi Creative Commons Attribution-Share Alike 4.0 Internasional. 


\section{Pendahuluan}

Kesehatan masyarakat merupakan salah satu hal yang paling penting didunia ini, terutama pada wanita, kesehatan wanita sangat perlu untuk diperhatikan, terutama kesehatan reproduksi. Wanita memiliki tahap dalalm hidupnya dimana diantaranya mengandung dan melahirkan. Dalam tahapan tersebut dikenal sebuah istilah abortus. Abortus adalah salah satu masalah yang sering menyerang wanita. Dampak dari abortus adalah kesakitan bahkan sampai dapat meyebabkan kematian pada ibu karena komplikasi dari pendarahan. Di negara berkembang, termasuk didalamnya Indonesia sendiri pada tahun 2014 yang dikutip dari World Health Organization menyebutkan ada sejumlah 800 wanita atau $99 \%$ diantaranya yang meninggal karena proses kehamilan dan komplikasi pada saat mengandung. ${ }^{1}$

Sejak tahun 1991-2007 Angka Kematian Ibu (AKI) di Indonesia mengalami penurunan dari 390 ibu yang meninggal menjadi 228 per 100.000 kelahiran hidup. Namun, berdasarkan hasil Survey Demografi Kesehatan Indonesia (SDKI) pada tahun 2013-2015, Indonesia mengalami penurunan dengan jumlah 307 ibu yang meninggal per 100.000 kelahiran hidup. Hal ini, berdasarkan dari target pemerintah Indonesia yang ingin dicapai sebesar 125 kematian ibu per 100.000 kelahiran hidup. $^{2}$

Salah satu provinsi di Indonesia yang paling banyak mengalami AKI adalah provinsi Jawa Barat, Kabupaten Bogor. Pada tahun 2014 terdapat 748 ibu yang meninggal angka tersebut naik 75 orang di tahun 2015. Banyak faktor yang berpengaruh terhadap tingginya kasus kematian ibu, yaitu keterlambatan penanganan pasien di pelayanan fasilitas kesehatan dan kurang gizi, nutrisi dan vitamin. ${ }^{3}$ Penyebab utama kematian ibu dalam bidang obstetri yaitu perdarahan (46,7\%), ekslamsi $(14,6 \%)$, infeksi (8,0\%), dan partus lama (6,5\%), anemia (54,6\%) dan kurang energy sebesar $(9,8 \%)$. Abortus merupakan penyakit komplikasi terbanyak pada kehamilan selain dari miscarriage, early pregnancy loss. Penyebab abortus (early pregnancy loss) bervariasi dan sering diperdebatkan. Umumnya lebih dari satu penyebab yaitu penyebab genetik, antomik, autoimun, penyebab infeksi, faktor lingkungan, faktor hormonal, faktor hematoma. ${ }^{4}$

Abortus sendiri dibagi menjadi 4 yaitu, fase permulaan yang dialami oleh ibu hamil, pada fase ini abortus ditandai dengan pendarahan. Pendarhan terjadi pada pervaginam ostium uteri yang masih dalam keadaan tertutup. Fase awal ini dikenal dengan istilah abortus iminens abortus ysng konsepsinya masih dalam keadaan baik bagi kandungan. Fase kedua yaitu dikenal dengan istilah abortus insipiens atau abortus tingkat sedang. Meskipun masih berada pada tingkat sedang namun pada fase ini ostium uteri mulai terbuka, dan mengancam ditandai dengan serviks mulai mendatar. Konsepsi masih dalam proses pengeluaran. Fase ketiga yaitu pada usia kandungan 20 minggu, atau janin kurang dari 500 gram. Konsepsi pada fase ini mulai keluar dari vakum uteri. Adapun abortus terakhir yaitu dimana kehamilan yang kurang dari 20 minggu meninggal dan ditandai dengan embrio dan hasil konsepsi seluruhnya masih terasa dalam kandungan. Abortus habitualis adalah abortus spontan yang terjadi $3 \mathrm{x}$ atau lebih berturut-turut. ${ }^{4}$

Seorang peneliti yang bernama Winkjosastro mengungkapkan bahwa syok, infeksi, pendarahan, dan perforasi merupakan komplikasi yang sangat berbahaya pada abortus. Apabila telah terjadi pendarahan pada abortus maka hanya dapat diatasi dengan transfuse darah, atau dilakukan penggosongan uterus dari sisa yang dihasilkan oleh konsepsi. Apabila penderita abortus tidak ditangani tepat waktu maka bisa saja mengakibatkan kematian. Penderita abortus yang juga harus 
mendapat perhatian lebih yaitu apabila terjadi perforasi uterus pada kerokan, terutama apabila terdapat di hiperetrofleksi. Apabila perforasi benar terjadi maka langkah pertama yang harus dilakukan adalah mencari tahu luasnya cedera agar dapat dilakukan tindakan pertama untuk mencegah terjadinya infeksi. Asepsis dan anatisepsis sangat diperlukan pada penderita ini, sebab infeksi dapat terjadi disekitara abortus terutama pada abortus inkomplit maupun abortus buatan. Dalam hal ini apabila infeksi terjadi diluar pengendalian maka terjadilah peritonitis atau sepsis, atau biasa dikenal dengan istilah syok karena pendarahan yang terjadi. Selain itu orang dengan abortus inkomplit akan mengalami mual dan lemas sehingga dapat membahayakan hidupnya. ${ }^{6}$

Berbagai penelitian telah dilakukan, dari hasil penelitian tersebut menyebutkan rata-rata perjam telah terjadi kasus abortus sebanyak 114, dari hasil tersebut dari semua kehamilan terdapat $15-20 \%$ yang diungkap oleh study kasus sehingga dapat dikatakan bahwa kasus abortus telah mendekati 50\%. Kasus tersebut dapat terjadi karena beberapa factor, diantaranya karena chemical loss yang tinggi selama 2-4 minggu setelah konsepsi. Faktor lain yang mempengaruhi adalah kegagalan kehamilann yang disebabkan oleh kegagalan gamet (contoh sperma dan disfungsi oosit). ${ }^{4}$

Kematian merupakan sesuatu yang sangat mengerikan dikalangan masyarakat, abortus merupakan salah satu penyebab kematian yang banyak terjadi. Pada umumnya terjadi pada ibu yang sedang hamil, hamil yang mengakibatkan pendarahan sampai pada pendarahan. Pendarahan tersebut terjadi selama abortus yang juga mengakibatkan anemia sehingga peluang resiko kematian pada ibu hamil semakin besar. Abortus yang sangat berbahaya adalah abortus inkomplit. Untuk menghentikan pendarahan biasanya dilakukan penanganan pada konsepsi yang masih tertinggal pada placental site.

Ada dua jenis abortus yang sering terjadi, yaitu abortus spontan dan abortus abortus provokatus. Abortus spontan adalah jenis abortus yang terjadi begitu saja, tanpa adanya tindakan sebelumnya. Jenis abortus ini tidak mengenal usia dan hanya terjadi sedikit gejala. Sedangkan abortus probokatus adalah abortus dengan kesengajaan. Abortus spontan biasanya 15-20\% adalah kehamilan ektopik.

Abortus berulang bisa saja terjadi menurut Prawirohardjo berdasarkan kasus yang ditemuinya 3-5\%. Beberapa studi juga mengungkapkan bahwa apabila seseorang telah mengalami abortus 1 kali maka akan beresiko sampai 15\% akan mengalami abortus susulan. Dan apabila terjadi sampai dua kali maka akan beresiko 25\%, dan seterusnya akan berurutan 30-45\% setelah kejadian 3 kali.

Pelayanan antenatal merupakan salah satu upaya penanganan yang diungkapkan oleh Wirakusuma untuk safe motherhood. Upaya ini dinilai dapat mencegah adanya komplikasi obstetric, upaya ini juga disebut dengan istilah empat pilar safe motherhood. Selain adanya pencegahan komplikasi, upaya ini juga diharapkan untuk dapat memastikan komplikasi yang terjadi sejak awal sehingga dapat ditangani sesegera mungkin. Di Indonesia sendiri, sudah ada perdarahan $67 \%$, pre eklamsia dan eklamsia $8 \%$, dan komplikasi abortus $10 \% 5$, yang menyebabkan kematian pada ibu hamil. ${ }^{8}$

Dari hasil studi pendahuluan diperoleh, pada tahun 2015 didapatkan angka kejadian abortus sebanyak 215 ibu hamil yang mengalami abortus. Dan pada tahun 2016 didapatkan angka kejadian abortus sebanyak $172 \mathrm{ibu}$ yang mengalami abortus dan pada tahun 2017 didapatkan angka kejadian abortus sebanyak 145 ibu yang mengalami abortus di RSUD Cibinong. Oleh karena itu, peneliti akan mengambil judul "Faktor-Faktor yang Berhubungan dengan Kejadian Abortus Inkomplit di RSUD Cibinong Kabupaten Bogor tahun 2017". 


\section{Metode}

Dalam penelitian ini menggunakan penelitian yang menggambarkan secara langsung kasus yang terjadi pada masyarakat, dimana dikenal dengan istilah penelitian deskriptif. Penelitian deskriptif ini dalam bidang kesehatan dilakukan dengan peneliti terjun langsung dalam lingkup masyarakat untuk memotret kasus-kasus yang terjadi pada masyarakat itu sendiri, sekelompok orang, atau bahkan pada komunitas tertentu. ${ }^{9}$ Selain metode tersebut, dalam penelitian ini objek atau subjek yang ada ditetapkan oleh peneliti untuk dijadikan kesimpulan. Wilayah generasi dalam tindakan kasus tersebut dikenal dengan istilah populasi dimana memiliki karakteristik dan kualitas yang tertentu. ${ }^{10}$ Dalam hal ini populasi akan dijelaskan secaraa detail tentang kelompok yang diteliti berdasarkan spesifik tertentu bahkan sampai batas sasaran yang diambil unutk penelitian. ${ }^{9}$

Populasi dalam penelitian ini adalah seluruh ibu hamil yang mengalami abortus inkomplit di RSUD Cibinong terdapat 145 kasus, sempel yang masuk kedalam kriteria penelitian terdapat 86 kasus Abortus Inkomplit. Sampel dalam penelitian ini diambil dari sejumla karakteristik yang peneliti gunakan dalam populasi. ${ }^{11}$ Dengan Bahasa lain sampel merupakan sasaranyang peneliti gunakan untuk mewakili seluruh populasi. ${ }^{9}$ Sebagai contoh sederhana, populasi berarti seluruh dari sasaran yang ditetapkan, sedangkan sampel lebih mencakup inti dari populasi. Dalam hal ini tentu lebih memudahkan peneliti dari berbagai aspek, seperti waktu, tenaga, dana, dan sebagainya. Maka dari itu sampel yang digunakan harus benar-benar tepat untuk menjadi penjelasan dari seluruh populasi. ${ }^{10}$

Sesuai dengan uraian yang diatas maka sampel yang peneliti ambil yaitu sebagian yang dapat mewakili populasi yang sesuai dengan kriteria inklusi sebanyak 86 orang.

Jenis data yang digunakan pada penelitian ini adalah data sekunder. Pengumpulan data dilakukan dengan cara mengambil rekamedik dirumah sakit umum daerah cibinong. Setelah data terkumpul, diseleksi kelengkapannya dalam pengisian, kemudian dilakukan pengolahan data sebagi berikut:

Penyuntingan Data (editing) Data yang telah diberi oleh pihak rumah sakit (rekamedik) perlu disunting (edit) terlebih dahulu. 2. Penandaan Data (Coding) Data yang telah ada setelah dilakukan koreksi, ketepatan dan kelengkapannya, kemudian decoding agar memudahkan dalam proses entry data yang dilakukan. ${ }^{9}$ Analisis Data Memasukan Data (Entry) Kegiatan memasukan data ke dalam komputer dengan menggunakan program software komputer. Dalam penelitian ini yang harus benarbenar diperhatikan ada analisis data, data harus diolah dengan sebenar-benarnya menggunakan Teknik-teknik tertentu. Data kualitatif diolah dengan analisis kuatitatif, dan data kuantitatif sendiri juga diolah dengan analisis kuantitatif. Proses komputerisasi dapat digunakan dalam analisis data kuantitatif. Dalam pengolahan ini mencakup tabulasi data dan perhitungan statisti, bila perlu diuji statistik. $^{9}$

Untuk variabel itu sendiri, peneliti menggunakna analisis univariat, Data yang didapatkan akan dijelaskan dalam pengujian statistic kolerasi yang diproses dalam table frekuensi. Dimana hal ini bertujuan untuk menggambarkan atau menjelaskan secara detail responden sesuai dengan karakteristik masing-masing. Sedangkan untuk dua variable yang diduga saling mempengaruhi atau mempunyai hubungan satu sama lain digunakan analisa bivariat. Seperti penngertian dari Analisa bivariat itu sendiri, Analisa ini digunakan untuk mengetahui apakah ada hubungan atau kolaborasi 


\section{J INDONESIA JOURNAL of Miduifery sciences}

antar dua variable yang didapatkan juga untuk mengetahui perbedaan antara dua variable tersebut dengan menggunakan uji chi square.

Hasil

Tabel 1. Distribusi Frekuensi Responden Kejadian Abortus, Usia, Paritas, Abortus Sebelumnya di RSUD Cibinong Kabupaten Bogor Tahun 2017

\begin{tabular}{lll}
\hline Variabel & Frekuensi & Presentase \\
\hline Kejadian Abortus & & 62.8 \\
\cline { 2 - 3 } Ya & 54 & 37.2 \\
\cline { 2 - 3 } Tidak & 32 & 37.2 \\
\hline Usia & 32 & 62.8 \\
Berisiko $<20 \&>35$ thn & 54 & 23.3 \\
Tidak Berisiko 20-30thn & & 55.8 \\
\hline Paritas & 20 & 20.9 \\
\cline { 2 - 3 } Primipara & 48 & 43.0 \\
Multipara & 18 & 57.0 \\
Grandemultipara & & \\
\hline Abortus Sebelumnya & 37 & \\
Pernah & 49 & \\
Tidak Pernah & &
\end{tabular}

Sumber: Data peneliti tahun 2017

Berdasarkan pada tabel 1 menunjukan karakteristik responden dapat dilihat bahwa yang mengalami kejadian abortus berjumlah $62,8 \%$ (54 responden). yang tidak mengalami kejadian abortus berjumlah 37.2\% (32 responden). Berdasarkan pada tabel 1 menunjukan karakteristik responden usia di RSUD Cibinong Kabupaten Bogor dapat dilihat bahwa usia tidak berisiko 20-30 thn berjumlah $62,8 \%$ ( 54 responden). usia berisiko $<20->35$ thn berjumlah $37.2 \%$ (32 responden). Berdasarkan pada tabel 1 menunjukan karakteristik responden paritas di RSUD Cibinong Kabupaten Bogor dapat dilihat bahwa paritas primipara berjumlah $23.3 \%$ (20 responden), paritas multipara berjumlah $55,8 \%$ (48 responden). sedangkan paritas grande multipara berjumlah 20.9\% (18 responden). Berdasarkan pada tabel 1 menunjukan karakteristik responden abortus sebelumnya di RSUD Cibinong dapat dilihat bahwa ibu yang pernah abortus sebelumnya berjumlah 43\% (37 responden). yang tidak pernah abortus sebelumnya berjumlah 57\% (49 responden).

Tabel 2. Hubungan Usia, Paritas, Abortus Sebelumnya terhadap Kejadian Abortus Inkomplit di RSUD Cibinong Kabupaten Bogor

\begin{tabular}{|c|c|c|c|c|c|c|c|}
\hline \multirow{3}{*}{ Variabel } & \multicolumn{4}{|c|}{ Kejadian Abortus Inkomplit } & \multirow[b]{3}{*}{ Total } & \multirow{3}{*}{$\begin{array}{c}\text { P- } \\
\text { value }\end{array}$} & \multirow[b]{3}{*}{ OR } \\
\hline & & & & & & & \\
\hline & $\mathbf{F}$ & $\%$ & $\mathbf{F}$ & $\%$ & & & \\
\hline
\end{tabular}




\section{J INDONESIA JOURNAL \\ of Miduifery sciences}

\begin{tabular}{lccccccc}
\hline Usia & & & & & & \\
$\quad$ Berisiko $<20 \&>35$ thn & 13 & 24.1 & 41 & 79.5 & 54 & 0.001 & 0.217 \\
$\quad$ Tidak Berisiko 20-30 thn & 19 & 59.4 & 13 & 40.6 & 32 & & \\
$\quad \begin{array}{l}\text { Paritas } \\
\quad \text { Primipara }\end{array}$ & 8 & 14.8 & 12 & 37.5 & 20 & & \\
$\quad$ Multipara & 36 & 66.7 & 12 & 37.5 & 48 & 0.019 & - \\
$\quad$ Grandemultipara & 10 & 18.5 & 8 & 25.0 & 18 & & \\
$\quad \begin{array}{l}\text { Abortus Sebelumnya } \\
\quad \text { Pernah }\end{array}$ & 29 & 53.7 & 25 & 46.3 & 54 & 0.009 & 3.480 \\
$\quad$ Tidak Pernah & 8 & 25.0 & 24 & 75.0 & 32 & & \\
\hline
\end{tabular}

Sumber: Data peneliti tahun 2017

Berdasarkan tabel 2 dibawah ini didapatkan bahwa dari 86 responden didapatkan bahwa 13 responden $(24.1 \%)$ dari 54 responden yang memiliki usia berisiko kejadian abortus inkomplit serta memiliki kemungkinan kejadian abortus inkomplit, serta 19 responden (59.4\%) dari 32 memiliki usia berisiko kejadian abortus inkomplit serta memiliki kemungkinan kejadian abortus inkomplit. Kemudian didapatkan bahwa 41 responden (75.9) dari 54 responden yang memiliki usia risiko kejadian abortus inkomplit namun masuk kedalam usia tidak berisiko mendapatkan kejadian abortus inkomplit. Dan 13 responden (40.6\%) dari 32 responden yang memiliki usia risiko kejadian abortus inkomplit namun masuk kedalam usia tidak berisiko mendapatkan kejadian abortus inkomplit. Hasil uji statistik diperoleh p-value $=0,001$ dengan tingkat kemaknaan $(\alpha)=0,05$. Sehingga dapatkan disimpulkan bahwa ada hubungan yang bermakna antara usia dengan kejadian abortus inkomplit. Dari nilai Odd Ratio yang diperoleh dapat disimpulkan bahwa usia dan kejadian abortus inkomplit dapat berpeluang sebesar 0.217 .

Berdasarkan tabel 2 diatas didapatkan bahwa dari 86 responden didapatkan bahwa dari 54 responden paritas primipara yang terjadi abortus inkomplit sebanyak 8 responden (14.8\%), sedangkan dari 32 responden tidak paritas primipara yang terjadi abortus inkomplit sebanyak 12 responden $(37.5 \%)$. Kemudian dari 54 responden paritas multipara yang terjadi abortus inkomplit sebanyak 36 responden $(66.7 \%)$, serta dari 32 responden tidak paritas multipara yang terjadi abortus inkomplit sebanyak 12 responden (37.5\%). Kemudian dari 54 responden paritas grandemultipara yang terjadi abortus inkomplit sebanyak 10 responden (18.5\%), serta dari 32 responden tidak paritas grandemultipara yang terjadi abortus inkomplit sebanyak 8 responden $(25.0 \%)$. Hasil uji statistik diperoleh $p$ value $=0,019$ dengan tingkat kemaknaan $(\alpha)=0,05$. Sehingga dapatkan disimpulkan bahwa ada hubungan yang bermakna antara paritas dengan kejadian abortus inkomplit.

Berdasarkan tabel 2 diatas didapatkan bahwa dari 86 responden didapatkan bahwa dari 54 responden yang pernah memiliki riwayat abortus sebelumnya yang terjadi abortus inkomplit sebanyak 29 responden (53.7\%), sedangkan dari 32 responden pernah memiliki riwayat abosrtus sebelumnya yang terjadi abortus inkomplit sebanyak 8 responden (25.0\%). Kemudian dari 54 responden yang tidak pernah memiliki riwayat abortus sebelumnya yang terjadi abortus inkomplit sebanyak 25 responden (46.3\%), serta dari 32 responden tidak pernah memiliki riwayat abortus sebelumnya yang terjadi abortus inkomplit sebanyak 24 responden (75.0\%). Hasil uji statistik diperoleh p-value $=0,009$ dengan tingkat kemaknaan $(\alpha)=0,05$. Sehingga dapatkan disimpulkan bahwa ada hubungan yang bermakna antara abortus sebelumnya dengan kejadian abortus inkomplit. Dari nilai Odd Ratio yang 


\section{J INDONESIA JOURNAL \\ of Miduifery sciences}

diperoleh dapat disimpulkan bahwa abortus sebelumnya dan kejadian abortus inkomplit dapat berpeluang sebesar 3.480 .

\section{Pembahasan}

Dari hasil penelitian ini distribusi frekuensi usia di RSUD Cibinong Kabupaten Bogor yaitu usia berisiko $<20$ dan $>35$ tahun sebanyak 32 orang $37.2 \%$ dan usia tidak berisiko $20-20$ tahun sebanyak 54 orang $62.8 \%$. Usia dalam penelitian ini mayoritas berada pada usia $20-35$ tahun. Dari hasil penelitian ini distribusi frekuensi paritas di RSUD Cibinong Kabupaten Bogor bervariasi yaitu primipara sebanyak 20 orang $23.3 \%$, paritas multipara sebanyak 48 orang $5555.8 \%$, paritas grandemultipara sebanyak 18 orang $20.9 \%$. Mayoritas paritas dalam penelitian ini berada pada paritas multipara. Dari hasil penelitian ini distribusi frekuensi abortus sebelumnya di RSUD Cibinong Kabupaten Bogor yang pernah memiliki riwayat abortus sebanyak 37 orang $43.0 \%$, sedangkan yang tidak memiliki riwayat abortus sebanyak 49 orang $57 \%$.

\section{Hubungan Usia dengan Abortus terhadap Kejadian Abortus Inkomplit di RSUD Cibinong Kabupaten Bogor}

Analisis bivariat yang digunakan pada penelitian ini adalah uji Chi Square untuk mengetahui apakah ada hubungan usia dengan abortus terhadap kejadian abortus inkomplit di Rsud Cibinong Kabupaten Bogor.

Hasil penilitian ini diperoleh yaitu ada hubungan yang signifikan antara usia dengan abortus terhadap kejadian abortus inkomplit, hasil uji statistik diperoleh P-value $=0,001$ dengan tingkat kemaknaan $(\alpha)=0,05$. Dengan kata lain P-value $<0,05$ dapat diambil kesimpulan bahwa Ho ditolak dan Ha diterima yang artinya ada hubungan yang signifikan antara ada hubungan usia dengan abortus terhadap kejadian abortus inkomplit di RSUD Cibinong Kabupaten Bogor. Berdasarkan nilai Odd Ratio yang diperoleh yaitu 0.217 dapat disimpulkan bahwa usia terhadap kejadian abortus inkomplit mempunyai peluang 0.217 kali.

Hal ini sesuai dengan teori S. Prawirohardjo yang menjelaskan bahaya kehamilan pada ibu muda, dimana kehamilan yang terjadi diusia muda tanpa adanya persiapan akan mengakibatkan stress pada ibu, dalam hal ini juga akan menyebabkan kondisi tidaka stabil dan tidak terpelihara dengan baik yang menjadi peluang abortus meningkat setiap tahunnya. Dari ibu hamil dengan usia 35 tahun, $42,9 \%$ diantaranya mengalami abortus, selanjutnya usia 30 tahun sampai dengan 25-29 tahun. Hal tersebut dikarenakan pada usia 35 tahun rawan akan hamil terjadi pada ibu, dalam hal ini juga ibu akan kehilangan kasih sayangnya karena sebelumnya telah mengalmai kehamilan dana tidak terjadi apa-apa

Kesehatan reproduksi seorang wanita berkaitan dengan usianya, sesuai dengan yang dijelaskan oleh Bobak, (2010) bahwa usia yang aman untuk hamil yaitu pada usia 20-35 tahun. Sedangkan usia diatas 35 tahun adalah usia rentang untuk terkena penyakit dan daya tahan tubuh pada usia tersebut mulai menurun. Sama halnya untuk melahirkan, usia yang efektif atau memiliki resiko rendah untuk abortus yaitu pada usia 25-35 tahun. Pada usia tersebut telah dinilai siap dan mampu untuk melahirkan dan merawat bayi, serta memiliki kasih sayang yang besar. Sehingga dapat disimpulkan bahwa ibu yang melahirkan dan anak yang dilahirkan dipengaruhi oleh umur ibu. 
Pada umumnya, masyarakatpun tidaka sedikit yang mengetahui bahwa usia yang paling aman untuk melahirkan adalah usia 20 sampai dengan usia 35 tahun, karena tidak memiliki resiko yang besar. Namun, hal itu tidak menjadi alasan bagi beberapa orang. Banyak yang pada usia dibawah 20 telah melahirkan dan pada usia diatas 35 tahun juga banyak yang terjadi. Padahal pada usia tersebut memiliki resiko yang besar untuk melahirkan karena adanya beragam faktor gangguan. Seorang peneliti yang bernama Winkjosastro mengungkapkan bahwa syok, infeksi, pendarahan, dan perforasi merupakan komplikasi yang sangat berbahaya pada abortus. Apabila telah terjadi pendarahan pada abortus maka hanya dapat diatasi dengan transfuse darah, atau dilakukan penggosongan uterus dari sisa yang dihasilkan oleh konsepsi. Ia juga telah menjelaskan bahwa usia sangat mempengaruhi kehamilan sampai dengan proses melahirkan. Reaproduksi yang belum sempurna secara tidak langsung belum memiliki mental yang cukup untuk melahirkan. Hal ini nisa mengakibatkan risiko komplikasi obstretrik seperti eklamsia, solusio plasenta, abortus inkomplit, persalinan macet, BBLR, toksemia, eklamsia, inersia uteri, perdarahan post-partum, serta kematian neonatus dan perinatal. Ketidaka matangan mental ini adalah yang berusia dibawah 20 tahun. Namun hal yang sama bisa terjadi pada usia diatas 35 tahun. Demikian juga ibu yang berumur di atas 35 tahun, bahkan memiliki 2 kali lipat dari resiko usia dibawah 20 tahun.

Penelitian sejalan dilakukan juga dengan Mariani 2012, dengan judul factor-faktor yang berhubungann dengan kejadian Abortus di Di Ruang Kebidanan Rumah Sakit Umum Daerah Zainoel Abidin Banda Aceh. Dari hasil penelitian yang dilakukan, ia mendaptkan hubungan antara usia ibu yang hamil dengan Abortus, dengan nilai P-value - 0.032 .

Pada tahun 2010 di RSUD Bekasi seorang peneliti juga yang bernama Royani Chairiyah dengan judul Faktor-faktor yang Mempengaruhi Ibu Hamil dengan Abortus juga menyatakan hal sama, yaitu antara usia ibu dengan abortus memiliki hubungana yang bermakna. Sejalan dengan penelitian Kusniati di Rumah Sakit Ibu dan Anak Kabupaten Banyumas Pada Tahun 2007. Dengan nilai P-value -0.000 .

Wanita dengan usia dibawah 20 tahun belum memiliki kematangan secara fisik dan mental, juga organ-organ reproduksi mereka belum cukup matang untuk melalui proses melahirkan, hal tersebut sangat mempengaruhi proses pertumbuhan janin oleh sebab itu wanita dibawah 20 tahun tidak disarankan untuk hamil. Hal demikian juga untuk wanita diatas 35 tahun, alat reproduksi mereka tidak sanggup lagi yang sangat memungkinkan abortus terjadi. Pernyataan tersebut didukung oleh beberapa asumsi dari berbagai peneliti.

\section{Hubungan Paritas dengan Abortus terhadap Kejadian Abortus Inkomplit di RSUD Cibinong Kabupaten Bogor}

Hasil penilitian ini diperoleh yaitu ada hubungan yang signifikan antara paritas dengan abortus terhadap kejadian abortus inkomplit, hasil uji statistik diperoleh $\mathrm{P}$-value $=0,019$ dengan tingkat kemaknaan $(\alpha)=0,05$. Dengan kata lain P-value $<0,05$ dapat diambil kesimpulan bahwa Ho ditolak dan Ha diterima yang artinya ada hubungan yang signifikan antara ada hubungan paritas dengan abortus terhadap kejadian abortus inkomplit di RSUD Cibinong Kabupaten Bogor.

Abortus juga harus diwaspadai pada ibu yang sering melahirkan. Sesuai dengan teori yang disebutkan pada tahun 2009 oleh S. Prawirohardjo, ia mengungkapkan bahwa ibu yang telah melahirkan sampai 4 kali atau lebih rahimnya akan teregang oleh adanya janin yanag berkelanjutan. 
Maka harus diperhatikan terhadap gangguan saat mengandung, melahirkan, dan nifas. Kejadian tersebut berisiko meningkat seiring dengan paritas ibu. ${ }^{7}$

Paritas adalah Janin yang dihasilkan oleh Rahim, atau bertambahnya anak secara terus menerus, dimana ibu memiliki lebih dari dua anak. Bisa tiga bahkan empat anak, dari anak pertama sampai terakhir. Teori ini diungkapkan oleh Bobak pada tahun 2010. Paritas tidak dipengaruhi oleh janin yang hidup, dengan artian janin hidup atau mati disebut dengan paritas viabilitas dicapai. Saat janin telah mencapai tahap viabilitas saat menjalani kehamilan, maka disebut dengan primipara. Sedangkan wnaita yang telah hamil dan menjalani jannin sampai 5 kali disebut dengan multipara. Paritas tinggi (Grandemultipara 5 atau lebih) viabilitas merupakan kapasitas hidup diluar uterus, sekitar 22 minggu periode menstruasi (20 minggu kehamilan) atau berat janin lebih dari 500 gram. ${ }^{18}$

Wanita yang sedang hamil disebut juga dengan gravida menurut Winkjosastro. Sedangkan wanita yang sedang hamil tapi kehamilannya merupakan yang pertama disbeut dengan primigravida. Dan para adalah seorang wanita hamil yang pernah melahirkan bayi yang dapat hidup (Viable). Wanita yang tidak pernah melahirkan bayi yang variable bahkan untuk pertama kalinya disebut dengan nullipara. Multipara atau pleuripara adalah seorang wanita yang pernah melahirkan bayi yang viable untuk beberapa kali. ${ }^{19}$

Hasil penelitian ini juga diperkuat oleh peneltian yang dilakukan oleh Mariani (2012) dengan judul: Faktor - Faktor yang Berhubungan dengan Kejadian Abortus di Ruang Kebidanan Rumah Sakit Umum Daerah Zainoel Abidin Banda Aceh bahwa terdapat hubungan bermakna (P-value - 0.007) Hal ini berarti terdapat hubungan antara paritas dengan kejadian abortus.

Pada penelitian lain oleh Abarsari (2010) di RSUD DR. Siaful Anwar Malang mendapatkan bahwa terdapat hubungan bermakna (P-value - 0.002). Pada penelitian lain yang dilakukan Lukitasari (2010) di RS H.M Ryacudu Kotabumi Lampung Utara yang mendapatkan bahwa terdapat hubungan yang signifikan (nilai $\mathrm{p}=0,0001$ ) antara frekuensi persalinan dengan kejadian abortus. Maka penelitian diatas selaras dengan hasil data penelitian ini.

Ibu hamil yang memiliki paritas yang tinggi cenderung memiliki otot Rahim yang lebih lemah daripada ibu dengan paritas primipara sebab Rahim yang lemah tidak mampu menyokong janin dengan sempurna. Kejadian tersebut sangat berisiko terhadap terjadinya abortus.

\section{Hubungan Abortus Sebelumnya dengan Abortus terhadap Kejadian Abortus Inkomplit Di Rsud Cibinong Kabupaten Bogor}

Hasil penilitian ini diperoleh yaitu ada hubungan yang signifikan antara abortus sebemnya dengan abortus terhadap kejadian abortus inkomplit, hasil uji statistik diperoleh P-value $=0,009$ dengan tingkat kemaknaan $(\alpha)=0,05$. Denga kata lain P-value $<0,05$ dapat diambil kesimpulan bahwa Ho ditolak dan Ha diterima yang artinya ada hubungan yang signifikan antara ada hubungan abortus sebelumnya dengan abortus terhadap kejadian abortus inkomplit di RSUD Cibinong Kabupaten Bogor. Berdasarkan nilai Odd Ratio yang diperoleh yaitu 3.480 dapat disimpulkan bahwa abortus sebelumnya terhadap kejadian abortus inkomplit mempunyai peluang 3.480 kali.

Abortus berulang bisa saja terjadi menurut Prawirohardjo berdasarkan kasus yang ditemuinya 3-5\%. Beberapa studi juga mengungkapkan bahwa apabila seseorang telah mengalami abortus 1 kali maka akan beresiko sampai $15 \%$ akan mengalami abortus susulan. Dan apabila terjadi sampai dua kali maka akan beresiko $25 \%$, dan seterusnya akan berurutan 30-45\% setelah kejadian 3 kali 


\section{J INDONESIA JOURNAL of Miduifery SCIENCES}

Penelitian yang sejalan juga dilakukan di Jepang pada tahun 2010. Peneliti ini bernama Baba et al, ia membuktikan penelitiannya tentang abortus dengan hasil OR yang senilai 1,9 wanita dengan riwayat 1 kali, OR 2.36 pada wanita yang memiliki 2 kali riwayat abortus dan OR 8,73 pada yang pernah mengalami 3 atau lebih abortus sebelumnya.

Lukitasari seorang peneliti yang juga meneliti tentang abortus pada tahun 2010, di RS H.M Ryacudu Kotabumi Lampung Utara. Lukitasari dalam penelitiannya mendapatkan hasil yang sama, yaitu antara ibu hamil dengan abortus memiliki hubungan yang signifikan. Yaitu dengan nilai $\mathrm{p}=$ $0,0001 .{ }^{16}$ Pada tahun 2012, Wahyuni juga meneliti penelitian yang sama di wilayah puskesmas Sungai Kakap Kabupaten Kubu Raya Kalimantan Barat. Dalam penelitiannya ia mendapatkan hasil yang sama dengan beberapa peneliti yang diebutkan diatas, yaitu abortus dengan ibu hamil memiliki hubungan yang signifikan (nilai $\mathrm{p}=0,04$ ). Dalam penelitiannya, ia juga menyatakan wanita yang mengalami abortus cenderung mengallmainya sampai beberapa kali (2,8 kali) dibandingkan dengan ibu atau yang belum pernah mengalami abortus. ${ }^{17}$

\section{Kesimpulan}

Ada hubungan usia dengan kejadian abortus inkomplit di RSUD Cibinong Kabupaten Bogor. Ada hubungan paritas dengan kejadian abortus inkomplit di RSUD Cibinong Kabupaten Bogor. Ada hubungan abortus sebelumnya dengan kejadian abortus inkomplit Di Rsud Cibinong Kabupaten Bogor.

Saran bagi peneliti, agar peneliti dapat meneliti lebih luas lagi variabel yang akan diteliti dan agar dapat menambah wawasan pengetahuan khususnya pada Abortus Inkomplit. Bagi pendidikan, dari hasil penelitian yang didapatkan dilapangan agar dapat dijadikan masukan bagi pengembangan ilmu dan pengetahuan serta menjadi sumber pustaka bagi mahasiswa yang akan datang. Bagi Lahan Peneliti, Perlunya penyebaran informasi secara merata tentang kesehatan reproduksi terutama kaum wanita sehingga mereka memiliki kesadaran akan dampak yang akan ditimbulkan karena abortus.

\section{Konflik Kepentingan}

Penelitian ini tidak ada konflik kepentingan apapun baik secara individu maupun organisasi

\section{Ucapan Terima Kasih}

Terimakasih kepada semua responden yang telah berkontribusi pada penelitian ini

\section{Pendanaan}

Sumber pendanaan pada penelitian ini adalah individu.

\section{References}

1. WHO. Maternal Mortality: World Health Organization; 2014.

2. Badan Pusat Statistik. Survei Demografi dan Kesehatan Indonesia (SDKI) Jakarta: Badan Pusat Statistik. 2015.

3. Dinas Kesehatan JABAR. Profil Kesehatan Tahun 2015.

4. Prawirohardjo, Sarwono. Ilmu Kebidanan Sarwono Prawirohardjo. Jakarta: PT. Bina Pustaka Sarwono Prawirohardjo. 2014.

5. Hanifa Wiknjosastro. Ilmu Kandungan. Edisi 2. EGC : Jakarta. 2008. 


\section{J INDONESIA JOURNAL of Miduifery SCIENCES}

6. Setia. Faktor-faktor Yang Berhubungan Dengan Kejadian Abortus Inkomplit di Rumah Sakit Umum Daerah dr.Zainoel Abidin Banda Aceh. 2016.

7. Prawirohardjo. Ilmu Kebidanan. Jakarta : Bina Pustaka Sarwono. Prawirohardjo. 2009.

8. Melti, Karakteristik Ibu Hamil Pada Kejadian Abortus. 2012.

9. Notoatmodjo. Metodologi Penelitian Kesehatan. Jakarta: PT Rineka Cipta. 2012.

10. Sugiyono. Metode Penelitian Pendidikan (Pendekatan Kuantitatif, Kualitatif dan R\&D). Penerbit CV. Alfabeta: Bandung. 2015.

11. Sujarweni, V. Wiratna. Metode Penelitian: Lengkap, Praktis, dan Mudah Dipahami. Yogyakarta: Pustaka Baru Press. 2014.

12. Notoatmodjo, S. Metodologi Penelitian Kesehatan. Jakarta : Rineka Cipta. 2010.

13. Hastono, S. P. Analisis Data. Jakarta: Universitas Indonesia. 2001.

14. Nurizka.2012.http://library.gunadarma.ac.id/repositpry/view/3773899/karakteristik-ibu-hamil-denganabortus-inkomplit-di-rsud-cibinong-2011.html. diunduh pada tanggal 15 juli 2017 pukul 11.00 wib.

15. Mariani. Faktor-faktor yang Berhubungan dengan Kejadian Abortus Inkomplit di Ruang Kebidanan Rumah Sakit Umum Daera DR. Zainoel Abidin Banda Aceh tahun 2012. Kebidanan STIKes U'Budiyah Banda Aceh. 2012.

16. Bobak. Buku Ajar Keperawatan Maternitas, Edisi 4, Penerbit Buku Kedokteran EGC, Jakarta. 2010.

17. Irham M, Susaldi S. Pengaruh Terapi Serum Iron Injeksi terhadap Peningkatan Nilai Hemoglobin Ibu Hamil dengan Anemia. Jurnal Kesehatan Pertiwi. 2019 Dec 19;1(1):32-7.

18. Purnama A, Afrina R, Shifa NA. Stress and Relationship with Cognitive Disorders of Post-Stroke Patients. STRADA Jurnal Ilmiah Kesehatan. 2020 May 3;9(1):1-5. 